\title{
When should a patient with prior COVID-19 infection be placed in isolation precautions if readmitted months later?
}

\author{
Leonard A. Mermel DO, ScM, AM (Hon), FSHEA, FIDSA, FACP ${ }^{1,2,3}$ (1) \\ ${ }^{1}$ Department of Medicine, Warren Alpert Medical School of Brown University, ${ }^{2}$ Division of Infectious Diseases, Rhode Island Hospital and ${ }^{3}$ Department of \\ Epidemiology and Infection Control, Rhode Island Hospital
}

To the Editor-In our hospital system, we do not consider the possibility of reinfection unless a patient had a positive SARS-CoV-2 PCR detected in a nasopharyngeal or nasal swab specimen $>3$ months from the first such positive PCR test or before then if immunocompromised. ${ }^{1}$ However, we have had patients previously admitted with COVID-19 pneumonia, discharged with waxing and waning SARSCoV-2 PCR positivity over the following 12-13 weeks, and found to be PCR positive with high PCR cycle target thresholds when they were readmitted. These patients' initial, severe infection has led to prolonged PCR positivity. ${ }^{2}$

Extracellular vesicles released from infected cells may promote infection prior to the development of an immune response. ${ }^{3}$ However, it is possible that RNA and/or other viral fragments released from cells over the days and weeks thereafter continue to prime the immune system ${ }^{4-6}$ such that reinfection during this time is unlikely, as it may be for weeks thereafter. If true, it makes more sense to not consider reinfection in immunocompetent patients until $>3$ months after the last positive SARS-CoV-2 PCR result rather than the first one. Such a policy would have profound implications: it would reduce the need for personal protective equipment that otherwise would be used for placing such patients in isolation precautions if readmitted. Future research is needed to determine whether viral fragments released from cells after active infection has resolved promote prolonged immunity to reinfection such that isolation precautions do not need to be reinstituted until 3 months after the last positive SARS-CoV-2 test.
Acknowledgments.

Financial support. No financial support was provided relevant to this article.

Conflicts of interest. The author reports no conflicts of interest relevant to this article.

\section{References}

1. Duration of Isolation and Precautions for Adults with COVID-19. Centers for Disease Control and Prevention website. https://www.cdc.gov/ coronavirus/2019-ncov/hcp/duration-isolation.html. Accessed July 28, 2020

2. Xu K, Chen Y, Yuan J, et al. Factors associated with prolonged viral RNA shedding in patients with coronavirus disease 2019 (COVID-19). Clin Infect Dis 2020 Apr 9 [Epub ahead of print]. doi: 10.1093/cid/ciaa351.

3. Wang J, Chen S, Bihl J. Exosome-mediated transfer of ACE2 (angiotensin converting enzyme 2) from endothelial progenitor cells promotes survival and function of endothelial cell. Oxid Med Cell Longev 2020 Jan 18 [eCollection]. doi: 10.1155/2020/4213541.

4. Jin CC, Zhu L, Gao L, Zhang S. Correlation between viral RNA shedding and serum antibodies in individuals with coronavirus disease 2019. Clin Microbiol Infect 2020 May 23 [Epub ahead of print]. doi: 10.1016/j.cmi. 2020.05.022.

5. Hassanpour M, Rezaie J, Nouri M, Panahi Y. The role of extracellular vesicles in COVID-19 virus infection. Infect Genet Evol 2020 Jun 13;85:104422. doi: 10.1016/j.meegid.2020.104422.

6. Gunasekaran M, Bansal S, Ravichandran R, et al. Respiratory viral infection in lung transplantation induces exosomes that trigger chronic rejection. $J$ Heart Lung Transplant 2020;39:379-388.
Author for correspondence: Dr. Leonard Mermel, E-mail: lmermel@lifespan.org

Cite this article: Mermel LA. (2021). When should a patient with prior COVID-19 infection be placed in isolation precautions if readmitted months later?. Infection Control \& Hospital Epidemiology, 42: 1022, https://doi.org/10.1017/ice.2020.408

(c) 2020 by The Society for Healthcare Epidemiology of America. All rights reserved. This is an Open Access article, distributed under the terms of the Creative Commons Attribution licence (http://creativecommons.org/licenses/by/4.0/), which permits unrestricted re-use, distribution, and reproduction in any medium, provided the original work is properly cited. 